\title{
ФОРМИРОВАНИЕ ИННОВАЦИОННЫХ МЕДИЦИНСКИХ КЛАСТЕРОВ КАК МЕХАНИЗМ РАСШИРЕНИЯ ОТЕЧЕСТВЕННОГО РЫНКА МЕДИЦИНСКОЙ ТЕХНИКИ
}

\author{
(c) 2021 Ожгихин И.В. \\ Санкт-Петербургский политехнический университет Петра Великого, Россия, Санкт-Петербург \\ () 2021 Рудская И.А. \\ Санкт-Петербургский политехнический университет Петра Великого, Россия, Санкт-Петербург \\ E-mail: iarudskaya@mail.ru
}

В статье проведен анализ применения кластерного подхода к отрасли медицинского оборудования. По результатам анализа были выявлены как слабые, так и сильные стороны существующих практик использования механизма. Даны рекомендации по совершенствованию данного механизма в условиях необходимости обеспечивать импортозамещение высокотехнологичного медицинского оборудования в рамках реализации программы диверсификации. Далее было проведено исследование в области существующих определений медицинского кластера, инновационного кластера, другие определения, связанные с рассматриваемыми и представленные в работах исследователей и нормативно-правовых актах, регулирующих здравоохранение в РФ. Дано итоговое определение инновационного медицинского кластера с учетом всех изученных и выделенных особенностей инновационных медицинских кластеров. Сформулированы предложения по перспективным направлениям использования данного механизма.

Ключевые слова: инновации, инновационный медицинский кластер, медицинская техника, механизм, конкурентоспособность, здравоохранение.

\section{Введение}

В условиях развития экономики, применение кластерного подхода получает все большее распространение. Если говорить об основных этапах развития кластеров в РФ с точки зрения использования данного механизма для развития инновационных медицинских кластеров, то необходимо начать с начала реализации Федеральной программы поддержки пилотных инновационных территориальных кластеров, запущенно в 2012 г. Минэкономразвития РФ. Данная программа способствовала увеличению кооперационных связей внутри кластеров, а также реализации производственного и научнотехнического потенциала территорий. В результате конкурсного отбора было отобрано 25 кластеров (впоследствии список увеличился до 27), расположенных на территориях с сильно развитыми инновациями. В перечень вошли кластеры из разных отраслей, в том числе в направлении «фармацевтика, биотехнологии и медицинская промышленность»:

- «Калужский кластер Фармацевтика, биотехнологии и биомедицина (отраслевая специализация кластера - проведение доклинических и клинических исследований, разработка, синтез и внедрение в производство фармацевтических субстанций и радиофармпрепаратов, промышленное производство готовых лекарственных средств (ГЛС) и фармацевтических субстанций, инфузионных растворов и парентерального питания)» [25];

- «Биотехнологический инновационный территориальный кластер Пущино (биотехнология для медицины, фармакология, биотехнологии в сельском хозяйстве, защита окружающей среды, промышленная биотехнология)» [14];

- «кластер ФИЗТЕХ XXI (фармацевтика и биомедицина; информационные, телекоммуникационные и космические технологии; энергоэффективность, новые материалы и новое оборудование)» [26];

- «кластер ядерно-физических и нанотехнологий в г. Дубне (трековые мембраны, системы безопасности, технологии ядерной медицины, композиционные материалы, нанобиотехнологии, радиационные технологии, технологии сверхпроводимости, проектирование сложных технических систем)» [40];

- «кластер медицинской, фармацевтической промышленности, радиационных технологий г. Санкт-Петербурга и Ленинградской 
области (медицинское приборостроение, производство лекарственных средств и фармацевтических субстанций, научно-исследовательская деятельность в области медицины и фармацевтики)» [27];

- «ядерно-инновационный кластер г. Димитровграда Ульяновской области (энергетика, ядерная медицина, материаловедение, поддержка конверсии технологий и расширения сфер применения ядерных технологий)» [53];

- «Алтайский биофармацевтический кластер (химико-фармацевтическое производство, биофармацевтическое производство, производство продуктов питания с заданными полезными свойствами, производство медицинской техники)» [8];

- «инновационный кластер информационных и биофармацевтических технологий Новосибирской области (информационные технологии, биофармацевтика, оборудование для медицины и биотехнологий)» [21];

- «инновационный территориальный кластер Фармацевтика, медицинская техника и информационные технологии (диагностика, медицинские приборы и оборудование, биоматериалы, фармацевтика)» [22].

Одна треть получивших поддержку пилотных инновационных кластеров занимаются фармацевтическими и биомедицинскими разработками, а не непосредственно медицинской техникой, однако, одним из основных направлений деятельности выбрали производство медицинского оборудования и приборов.

В 2016 г. Министерство экономического развития изменило систему поддержки кластеров и ввело в действие проект «Развитие инновационных кластеров - лидеров инвестиционной привлекательности мирового уровня». Данный проект делал акцент на следующих приоритетах:

- «достижение технологического лидерства;

- обеспечение эффективной системы коммерциализации технологий;

- поддержка быстрорастущих компаний среднего бизнеса («газелей»);

- содействие модернизации «якорных» предприятий;

- формирование системы привлечения инвестиций мирового уровня;

- адаптация системы образования к потребностям участников кластеров;

- создание эффективной системы управления кластера» [7].
В итоге конкурсного отбора разнообразные меры поддержки получили 11 кластеров из 11 регионов. При этом 10 регионов, кластеры из которых победили, входят в Ассоциацию инновационных регионов России. «В число победителей вошли следующие кластеры из сферы «фармацевтика, биотехнологии и медицинская промышленность:

- Инновационный кластер Фармацевтика, биотехнологии и биомедицина Калужской области;

- Консорциум инновационных кластеров Московской области;

- Научно-производственный кластер Сибирский наукополис;

- Инновационный территориальный кластер Smart Technologies Tomsk;

- Инновационный кластер Ульяновской области» [43].

Исходя их вышесказанного, можно сделать вывод, что более $45 \%$ кластеров-лидеров инновационной привлекательности, так или иначе связаны с медицинской промышленностью. Рассмотрим особенности их деятельности подробнее.

«Кластер Фармацевтика, биотехнологии и биомедицина Калужской области осуществляет свою деятельность с 2011 г. по следующим ключевым направлениям:

- разработка и производство готовых лекарственных средств и фармацевтических субстанций;

- ядерная медицина (медицинская диагностика и лучевая терапия, применяемые при лечении онкологических заболеваний) - воссоздание всего производственного медицинского комплекса от изотопов до оказания медицинской помощи;

- биотехнологии;

- производство медицинского оборудования и изделий медицинского назначения (широкий ассортимент изделий для лечебных, диагностических, профилактических, реабилитационных мероприятий, ухода за больными и инвалидами)» [25].

Консорциум инновационных кластеров - объединение ранее созданных «инновационных территориальных кластеров, включенных в федеральные программы поддержки и доказавших свою эффективность (ИТК Пущино, Дубна, ИТК Физтех-21) с другими научноисследовательскими и промышленными пред- 
приятиями области.

Основными направлениями деятельности Консорциума стали:

- биофармацевтическая промышленность;

- разработка и производство медтехники;

- беспилотные летательные аппараты;

- СВЧ-электроника [30].

Научно-производственный кластер Сибирский наукополис «представляет собой комплекс взаимосвязанных предприятий и организаций, обладающих передовыми научными, технологическими, образовательными и предпринимательскими компетенциями» [41, 47], объединяющий информационные технологии, биофармацевтику, биотехнологии, высокотехнологичные медицинские изделия, высокотехнологичные медицинские услуги. Ядро кластера формируют парковые объекты: «Академпарк Новосибирского Академгородка, Биотехнопарк Кольцово, Медицинский технопарк, Промышленный медицинский парк» [41].

Особенностью кластера

«SMART

TechnologiesTomsk» является разделение на проектные альянсы, в рамках которых и происходит основые взаимодействие участников кластера: «Проектный альянс № 1 Линейка активных фармацевтических ингредиентов и биофармсубстанций, Проектный альянс № 2 Техническое зрение: линейка кроссрыночных продуктов для воздушных, наземных и морских беспилотных аппаратов, Проектный альянс № 3 Многофункциональные информационнокоммуникационные системы для регионов с экстремальными природно-климатическими условиями, Проектный альянс № 4 Робототехнические системы и образовательная робототехника, включая системы локальной навигации, распределенные системы управления приводными устройствами, системы обмена данными, интеллектуальные сервоприводы и сенсорное окружение, Проектный альянс № 5 Цифровая медицина (Digital Health), Проектный альянс № 6 Решения для умного города (Smart City Solutions)» [28, 31].

«В инновационный кластер Ульяновской области входят два крупных объекта (Консорциум «Научно-образовательно-производственный кластер Ульяновск-Авиа и Ядерноинновационный кластер г. Димитровграда)» [52], крупные индустриальные компании - инвесторы и совокупность высокотехнологичных и инновационных предприятий малого и среднего бизнеса, работающих в таких отрас- лях как транспорт будущего, новые материалы, eHealth - электронное здоровье, возобновляемая энергетика и др. [23].

Данные примеры доказывают, что предприятия медицинской промышленности активно используют преимущества кластерного подхода к организации деятельности в направлении получения государственной поддержки. Тем не менее, существуют проблемы терминологии, связанные с отсутствием единого подхода к возможностям использования кластеров в медицине в целом и в производстве медицинской техники в частности.

В Стратегии развития медицинской науки предусматривалось, что «национальные исследовательские университеты должны стать основой формирования научно-образовательных кластеров. Такие кластеры должны включать научно-исследовательские лаборатории, факультеты и кафедры ведущих вузов страны, клиники научно-исследовательских центров и вузов, инновационные предприятия различных форм собственности» [35].

В 2015 г. на заседании Совета по развитию социальных инноваций субъектов РФ при Совете Федерации в докладе министра здравоохранения прозвучала идея, что «укрепление научных школ в России целесообразно проводить путем реализации кластерной модели развития». Подразумевалось, что основу такой модели составят инновационные кластеры, которые сформируют «научно-образовательно-производственные объединения» [38].

Для реализации положений Стратегии в 2015-2016 гг. были созданы два первых медицинских научно-образовательных кластера на базе Северо-Западного федерального медицинского исследовательского центра им. Алмазова и Российского национального исследовательского медицинского университета им. Н.И.Пирогова [38].

Результаты исследования и их обсуждение

По мнению авторов, основным трендом развития медицинского приборостроения в РФ должно стать применение инновационного подхода, что позволит повысить конкурентоспособность отечественной медицинской техники. Это особенно актуальную в условиях необходимости обеспечивать импортозамещение высокотехнологичного медицинского оборудования в рамках реализации программы диверсификации. Особо остро данная проблема наблюдается во 
время кризисных явлений экономики, в частности, вызванных пандемией COVID-19.

Одним из положительных результатов использования кластерного подхода является синергический эффект, особенно в сфере креативности элементов кластера. Совместная деятельность по достижению цели в кластере осуществляется, как правило, эффективнее [44-46]. Поэтому полагаем, что наивысшего совокупного социального и экономического эффекта производители медицинского оборудования смогут достичь в составе кластеров, следовательно, возникает необходимость создания и развития ин- новационных медицинских кластеров.

Однако анализ источников показал, что в настоящее время отсутствует определение инновационного медицинского кластера, отражающего все необходимые аспекты. Для создания собственного определения необходимо проанализировать существующие определения медицинского кластера, инновационного кластера, другие определения, связанные с рассматриваемыми и представленные в работах исследователей и нормативно-правовых актах, регулирующих здравоохранение в РФ. Изученные определения представлены в Таблице 1.

Таблица 1. Определение основных понятий инновационного медицинского кластера

\begin{tabular}{|c|c|c|}
\hline Понятие & Определение & Автор \\
\hline \multicolumn{3}{|c|}{ Медицинский кластер } \\
\hline $\begin{array}{l}\text { Медицинский } \\
\text { кластер }\end{array}$ & $\begin{array}{l}\text { «руппа географически взаимосвязанных организаций (постав- } \\
\text { щики, производители, посредники) и связанных с ними обра- } \\
\text { зовательных заведений, органов государственного управления, } \\
\text { инфраструктурных компаний и т.д., действующих в определен- } \\
\text { ной сфере и взаимодополняющих друг друга» }[9,20] .\end{array}$ & $\begin{array}{l}\text { Захарова Е.Н., Кова- } \\
\text { лева И.П. }\end{array}$ \\
\hline $\begin{array}{l}\text { Фармамедицинский } \\
\text { кластер }\end{array}$ & $\begin{array}{l}\text { «Организационная среда, обеспечивающая наиболее опти- } \\
\text { мальную структуру взаимоотношений различных организа- } \\
\text { ций медико-фармацевтического комплекса, обеспечивающая } \\
\text { интеграцию научных исследований фармацевтического и } \\
\text { медицинского профиля, кооперацию научных и производ- } \\
\text { ственных взаимосвязей в рамках био и нанотехнологических } \\
\text { инноваций» [51]. }\end{array}$ & $\begin{array}{l}\text { Толстопятенко М.А., } \\
\text { Зиньковская Н.В. }\end{array}$ \\
\hline $\begin{array}{l}\text { Медицинский } \\
\text { кластер }\end{array}$ & $\begin{array}{l}\text { «Совокупность разноуровневых медицинских учреждений, обе- } \\
\text { спечивающая технологии диагностического, лечебного, профи- } \\
\text { лактического, реабилитационного процессов в целом и пред- } \\
\text { ставляющая из себя единую информационно-аналитическую } \\
\text { систему, способную на базе современного аппаратного ком-- } \\
\text { плекса предоставлять любую информацию о соответствии } \\
\text { лечебного процесса принятым стандартам, в том числе юриди- } \\
\text { ческим, экономическим и т.д.» [49] }\end{array}$ & $\begin{array}{l}\text { Сунгатов Р.Ш., Кисе- } \\
\text { лев С. В., Сосновский } \\
\text { А.А }\end{array}$ \\
\hline $\begin{array}{l}\text { Медицинский } \\
\text { кластер }\end{array}$ & $\begin{array}{l}\text { «Объединения конкурентоспособных организаций, располо- } \\
\text { женных на одной территории и способных оказывать высоко- } \\
\text { качественные медицинские услуги» [19] }\end{array}$ & Жаворонков Е.П. \\
\hline $\begin{array}{l}\text { Медицинский } \\
\text { кластер }\end{array}$ & $\begin{array}{l}\text { «Инновационная модель, состоящая из однородных объектов } \\
\text { медицинского назначения, объектов инфраструктуры, инте- } \\
\text { грирования в уже имеющиеся ресурсы отрасли высшие обра- } \\
\text { зовательные учреждения, объекты медицинского назначения, } \\
\text { транспортные сети и кадровые ресурсы» [32] }\end{array}$ & Лазуткин М.Н. \\
\hline $\begin{array}{l}\text { Медицинский } \\
\text { кластер }\end{array}$ & $\begin{array}{l}\text { «Совокупность разнопрофильных лечебных учреждений, } \\
\text { объединенных единой целью оказания специализированной } \\
\text { медицинской помощи конкретным группам населения, страда- } \\
\text { ющим конкретным видом заболевания» [48] }\end{array}$ & Сосновский А.А. \\
\hline $\begin{array}{l}\text { Медицинский } \\
\text { кластер }\end{array}$ & $\begin{array}{l}\text { «Инновационная модель организации процесса оказания ме- } \\
\text { дицинской помощи, основанная на согласованных действиях } \\
\text { по реализации профильного отбора, лечения, реабилитации, } \\
\text { диспансерного наблюдения пациента (технологические цепоч- } \\
\text { ки) с целью эффективного восстановления здоровья» [8] }\end{array}$ & $\begin{array}{l}\text { Закон Алтайского } \\
\text { края «О внесении } \\
\text { изменений в закон } \\
\text { Алтайского края } \\
\text { «Об оказании меди- } \\
\text { цинской помощи на } \\
\text { территории Алтай- } \\
\text { ского края» }\end{array}$ \\
\hline
\end{tabular}




\begin{tabular}{|c|c|c|}
\hline $\begin{array}{l}\text { Медицинский } \\
\text { кластер }\end{array}$ & $\begin{array}{l}\text { «Совокупность взаимосвязанных и взаимодействующих } \\
\text { медицинских учреждений и организаций, обеспечивающих } \\
\text { медицинскую деятельность, которые оказывают качественные } \\
\text { медицинские услуги населению, используют инновационные } \\
\text { разработки в области фармацевтики и медицинского оборудо- } \\
\text { вания, а также используют образовательную, информацион-- } \\
\text { ную инфраструктуру, неотьемлемой частью которых являются } \\
\text { человеческие» ресурсы [33] }\end{array}$ & $\begin{array}{l}\text { Лебединская Ю. С., } \\
\text { Яковец О.Н. }\end{array}$ \\
\hline $\begin{array}{l}\text { Международный } \\
\text { медицинский } \\
\text { кластер }\end{array}$ & $\begin{array}{l}\text { «Совокупность инфраструктуры территории международного } \\
\text { медицинского кластера, участников проекта и механизмов } \\
\text { взаимодействия участников проекта» [1] }\end{array}$ & $\begin{array}{l}\text { Федеральный закон } \\
\text { от «О международ- } \\
\text { ном медицинском } \\
\text { кластере и внесении } \\
\text { изменений в отдель- } \\
\text { ные законодательные } \\
\text { акты Российской } \\
\text { Федерации» }\end{array}$ \\
\hline $\begin{array}{l}\text { Медицинский } \\
\text { кластер }\end{array}$ & $\begin{array}{l}\text { «Совокупность фармацевтических, лечебно-диагностических и } \\
\text { медико-профилактических учреждений, объединенных функ- } \\
\text { циональной зависимостью и единой информационной средой, } \\
\text { использующих в своей деятельности инновационные научные } \\
\text { разработки, целью функционирования которых является ока- } \\
\text { зание конкурентоспособной экстренной и плановой медицин- } \\
\text { ской помощи» [50] }\end{array}$ & $\begin{array}{l}\text { Титова Н. Ю., Тито- } \\
\text { ва Ю.В. }\end{array}$ \\
\hline $\begin{array}{l}\text { Глобальный } \\
\text { кластер высоко- } \\
\text { технологичной } \\
\text { медицины }\end{array}$ & $\begin{array}{l}\text { «Включает большое число организаций разных } \\
\text { отраслей, чьи продукция и услуги широко востребованы за } \\
\text { рубежом» [13] }\end{array}$ & $\begin{array}{l}\text { Е.А. Исланки- } \\
\text { на, Е.С. Куцен- } \\
\text { ко, Ф.Н.Филина, } \\
\text { В.И.Панкевич и др. }\end{array}$ \\
\hline $\begin{array}{l}\text { Кластер } \\
\text { мировых биомеди- } \\
\text { цинских исследо- } \\
\text { ваний }\end{array}$ & $\begin{array}{l}\text { «Преимущественно сфокусирован на внедрении научных } \\
\text { открытий во врачебную практику с опорой на сильные универ- } \\
\text { ситетские клиники и центры знаний» [13] }\end{array}$ & $\begin{array}{l}\text { Е.А. Исланки- } \\
\text { на, Е.С. Куцен- } \\
\text { ко, Ф.Н.Филина, } \\
\text { В.И.Панкевич и др. }\end{array}$ \\
\hline $\begin{array}{l}\text { Кластер междуна- } \\
\text { родного медицин- } \\
\text { ского туризма }\end{array}$ & $\begin{array}{l}\text { «Объединяет участников от здравоохранения } \\
\text { и индустрии гостеприимства, чтобы развивать новые ком- } \\
\text { плексные сервисы для пациентов, позволяющие совместить } \\
\text { лечение и отдых» [13] }\end{array}$ & $\begin{array}{l}\text { Е.А. Исланки- } \\
\text { на, Е.С. Куцен- } \\
\text { ко, Ф.Н.Филина, } \\
\text { В.И.Панкевич и др. }\end{array}$ \\
\hline $\begin{array}{l}\text { Медицинский } \\
\text { кластер }\end{array}$ & $\begin{array}{l}\text { «Инновационная модель организации процесса оказания ме- } \\
\text { дицинской помощи, основанная на согласованных действиях } \\
\text { по реализации профильного отбора, лечения, реабилитации, } \\
\text { диспансерного наблюдения пациента» [37] }\end{array}$ & Мещерякова Ж.В. \\
\hline $\begin{array}{l}\text { Медицинский } \\
\text { кластер }\end{array}$ & $\begin{array}{l}\text { «Комплексная структура, объединяющая территориально - } \\
\text { сконцентрированные и (или) функционально взаимосвязанные } \\
\text { учреждения, сочетающие медицинские, образовательные и } \\
\text { исследовательские возможности для производства и продви- } \\
\text { жения в практическое здравоохранение современных конку- } \\
\text { рентоспособных видов медицинской помощи (медицинских } \\
\text { инноваций)» }[12,34] .\end{array}$ & $\begin{array}{l}\text { Беляков В.К., Пи- } \\
\text { вень Д.В., Анто- } \\
\text { нов Д.П. }\end{array}$ \\
\hline $\begin{array}{l}\text { Медицинский } \\
\text { кластер }\end{array}$ & $\begin{array}{l}\text { Совокупность разноуровневых медицинских учреждений, } \\
\text { обеспечивающих } \\
\text { технологии диагностического, лечебного, профилактического, } \\
\text { реабилитационного процессов }[34,48] .\end{array}$ & А.А. Сосновский \\
\hline $\begin{array}{l}\text { Медицинский } \\
\text { кластер }\end{array}$ & $\begin{array}{l}\text { «Модель взаимодействия организаций в системе оказания ме- } \\
\text { дицинской помощи (здравоохранении), основанная на согла- } \\
\text { сованных действиях по лечению, реабилитации и наблюдению } \\
\text { пациента с целью эффективного восстановления его здоровья» } \\
{[29]}\end{array}$ & Ковалюнас Н.В. \\
\hline $\begin{array}{l}\text { Кластер } \\
\text { в медицине }\end{array}$ & $\begin{array}{l}\text { «Интеграция потенциалов (ресурсов) научных, медицинских, } \\
\text { образовательных, производственных организаций, распо- } \\
\text { ложенных в территориальной близости и обеспечивающих } \\
\text { непрерывное медицинское обслуживание, направленное на } \\
\text { сохранение здоровья человека» [18] }\end{array}$ & $\begin{array}{l}\text { Губин А.В., Овчинни- } \\
\text { ков Е.Н., Стогов М.В., } \\
\text { Городнова Н.В. }\end{array}$ \\
\hline
\end{tabular}




\begin{tabular}{|c|c|c|}
\hline $\begin{array}{l}\text { Медицинский } \\
\text { кластер }\end{array}$ & $\begin{array}{l}\text { «Новая комплексная структура в системе отечественного } \\
\text { здравоохранения, объединенная одним технологическим про- } \\
\text { цессом, конечным продуктом которого является медицинская } \\
\text { инновация, созданная усилиями всех участников, процесса, } \\
\text { включающего представителей науки, практического здравоох- } \\
\text { ранения, органов власти, медицинского образования и меди-- } \\
\text { цинского бизнеса» [11] }\end{array}$ & $\begin{array}{l}\text { Артамонова Г. В., } \\
\text { Данильченко Я.В., } \\
\text { Костомарова Т. С., } \\
\text { Черкасс Н.В., Барба- } \\
\text { раш Л. С. }\end{array}$ \\
\hline \multicolumn{3}{|c|}{ Инновационный кластер } \\
\hline $\begin{array}{l}\text { Инновационные } \\
\text { кластеры }\end{array}$ & $\begin{array}{l}\text { «Влююают большое количество новых компаний, возникаю- } \\
\text { щих в процессе коммерциализации технологий и результатов } \\
\text { научной деятельности, проводимых в высших учебных заведе- } \\
\text { ниях и исследовательских организациях» [36] }\end{array}$ & $\begin{array}{l}\text { «Методические реко- } \\
\text { мендации по реали- } \\
\text { зации кластерной } \\
\text { политики в субъектах } \\
\text { Российской Федера- } \\
\text { ции» }\end{array}$ \\
\hline Кластер & $\begin{array}{l}\text { «Совокупность особых экономических зон одного типа или не- } \\
\text { скольких типов, которая определяется Правительством Россий- } \\
\text { ской Федерации и управление которой осуществляется одной } \\
\text { управляющей компанией» [2] }\end{array}$ & $\begin{array}{l}\text { Федеральный закон } \\
\text { от «Об особых эко- } \\
\text { номических зонах в } \\
\text { Российской Федера- } \\
\text { ции» }\end{array}$ \\
\hline $\begin{array}{l}\text { Инновационные } \\
\text { кластеры }\end{array}$ & $\begin{array}{l}\text { «Прототип стратегических исследовательских консорциумов, } \\
\text { которые способствуют вовлечению на ранних стадиях раз- } \\
\text { работки технологий и продуктов различных бенефициаров, } \\
\text { включая крупных индустриальных партнеров, малый и сред- } \\
\text { ний бизнес, исследовательские организации и университеты, а } \\
\text { также краудсорсинговые платформы» [6] }\end{array}$ & $\begin{array}{l}\text { «Прогноз социально- } \\
\text { экономического } \\
\text { развития Российской } \\
\text { Федерации на } 2018 \\
\text { год и на плановый } \\
\text { период } 2019 \text { и } 2020 \\
\text { годов» }\end{array}$ \\
\hline $\begin{array}{l}\text { Территориально- } \\
\text { производственные } \\
\text { кластеры }\end{array}$ & «Реализуют конкурентный потенциал территорий» [3] & Правительство РФ \\
\hline $\begin{array}{l}\text { Инновационный } \\
\text { территориальный } \\
\text { кластер }\end{array}$ & $\begin{array}{l}\text { «Совокупность размещенных на ограниченной территории } \\
\text { предприятий и организаций (участников кластера), которая ха- } \\
\text { рактеризуется наличием: объединящей участников кластера } \\
\text { научно-производственной цепочки; механизма координации } \\
\text { деятельности и кооперации участников кластера; синергети- } \\
\text { ческого эффекта, выраженного в повышении экономической } \\
\text { эффективности и результативности деятельности каждого } \\
\text { предприятия за счет высокой степени их концентрации» [42] }\end{array}$ & $\begin{array}{l}\text { Министерство эконо- } \\
\text { мического развития } \\
\text { Российской Федера- } \\
\text { ции }\end{array}$ \\
\hline $\begin{array}{l}\text { Научно- } \\
\text { производственный } \\
\text { кластер }\end{array}$ & $\begin{array}{l}\text { «Договорная форма кооперации организаций, обеспечиваю- } \\
\text { щих и осуществляющих целенаправленную деятельность по } \\
\text { разработке, производству и продвижению продукции наноин- } \\
\text { дустрии на внутренние и внешние рынки высокотехнологич- } \\
\text { ной продукции» [4] }\end{array}$ & $\begin{array}{l}\text { Постановление Пра- } \\
\text { вительства } \\
\text { Российской Федера- } \\
\text { ции }\end{array}$ \\
\hline $\begin{array}{l}\text { Инновационно- } \\
\text { ориентированный } \\
\text { кластер }\end{array}$ & $\begin{array}{l}\text { «Объединение предприятий-поставщиков оборудования, } \\
\text { комплектующих, специализированных производственных и } \\
\text { сервисных услуг, научно-исследовательских и образовательных } \\
\text { учреждений, связанных отношениями территориальной бли- } \\
\text { зости и функциональной зависимости, в сфере производства и } \\
\text { реализации инновационного продукта (товаров, услуг)» [24] }\end{array}$ & $\begin{array}{l}\text { Стратегия развития } \\
\text { науки и инноваций } \\
\text { в Российской Феде-- } \\
\text { рации }\end{array}$ \\
\hline $\begin{array}{l}\text { Инновационный } \\
\text { кластер }\end{array}$ & $\begin{array}{l}\text { «Группа независимых предприятий - инновационных старта- } \\
\text { пов, малых, средних и крупных фирм, а также исследователь- } \\
\text { ских организаций - действующих в одном секторе и регионе } \\
\text { и нацеленных на стимулирование инновационной активности } \\
\text { посредством интенсивного взаимодействия, совместного ис- } \\
\text { пользования мощностей и обмена знаниями, компетенциями, } \\
\text { обеспечения вклада в трансферт технологий, создание сетей } \\
\text { сотрудничества и распространение информации между субъек- } \\
\text { тами кластера» [54] }\end{array}$ & $\begin{array}{l}\text { Community } \\
\text { Framework for State } \\
\text { Aid for Research and } \\
\text { Development and } \\
\text { Innovation }\end{array}$ \\
\hline
\end{tabular}




\begin{tabular}{|c|c|c|}
\hline $\begin{array}{l}\text { Инновационный } \\
\text { кластер }\end{array}$ & $\begin{array}{l}\text { «лластер, сформированный на базе или имеющий в своем } \\
\text { составе центры генерации научных знаний, центры генерации } \\
\text { бизнес идей, центры подготовки высококвалифицированных } \\
\text { специалистов; выпускающий продукцию, обладающую долго- } \\
\text { срочными конкурентными преимуществами; действующий на } \\
\text { перспективных растущих рынках или формирующий новые } \\
\text { рынки сбыта» [39] }\end{array}$ & Монастырный Е.А. \\
\hline $\begin{array}{l}\text { Инновационный } \\
\text { кластер как } \\
\text { подсистема регио- } \\
\text { нальной инноваци- } \\
\text { онной системы }\end{array}$ & $\begin{array}{l}\text { «Совокупность: элементов кластера, имеющих свою внутрен- } \\
\text { нюю структуру (Наука, Образование, Организации инфра- } \\
\text { структуры, Крупные предприятия, Малый и средний бизнес); } \\
\text { взаимосвязей между элементами, выражающихся в финансо- } \\
\text { вых, информационных, материальных и человеческих потоках, } \\
\text { интенсивность которых выше, чем в системе в целом; связей } \\
\text { кластера с региональной инновационной системой» [39]. }\end{array}$ & Монастырный Е.А. \\
\hline $\begin{array}{l}\text { Инновационный } \\
\text { кластер }\end{array}$ & $\begin{array}{l}\text { «Объединение различных организаций (промышленных } \\
\text { компаний, технопарков, бизнес-инкубаторов, научно- } \\
\text { исследовательских центров, лабораторий, учебных заведений, } \\
\text { кредитных организаций, инвестиционных и инновационных } \\
\text { компаний, венчурных фондов, общественных организаций и } \\
\text { т.д.), позволяющее использовать преимущества внутрифир- } \\
\text { менной иерархии и рыночного механизма, что дает возмож- } \\
\text { ность более быстро и эффективно распределять новые знания, } \\
\text { новые открытия и изобретения» [15] }\end{array}$ & Бирюков А.В. \\
\hline $\begin{array}{l}\text { Инновационный } \\
\text { кластер }\end{array}$ & $\begin{array}{l}\text { «елостная система новых продуктов и технологий, взаимосвя- } \\
\text { занных между собой и сконцентрированных на определенном } \\
\text { отрезке времени и в определенном экономическом простран- } \\
\text { стве» [16] }\end{array}$ & Бирюков А.В. \\
\hline $\begin{array}{l}\text { Региональный } \\
\text { инновационный } \\
\text { кластер }\end{array}$ & $\begin{array}{l}\text { «Совокупность учреждений и организаций различных форм } \\
\text { собственности, находящихся на территории региона и осу- } \\
\text { ществляющих создание и распространение новых знаний, } \\
\text { продуктов и технологий, а также организационно-правовые } \\
\text { условия их хозяйствования, определенные совокупным влия- } \\
\text { нием государственной научной и инновационной политики, } \\
\text { региональной политики, проводимой на федеральном уровне и } \\
\text { социально-экономической политики региона» [24] }\end{array}$ & $\begin{array}{l}\text { Казанцев А.К., Ники- } \\
\text { тина И.А. }\end{array}$ \\
\hline $\begin{array}{l}\text { Кластер инноваци- } \\
\text { онного вида }\end{array}$ & $\begin{array}{l}\text { «Целенаправленно сформированная группа предприятий, } \\
\text { функционирование которых происходит на базе центров гене- } \\
\text { рирования бизнес-идей и научных новейших знаний, а также } \\
\text { подготовки специалистов с высоким уровнем квалификации» } \\
\text { [17]. }\end{array}$ & $\begin{array}{l}\text { Глубокий А., Акулич } \\
\text { М. }\end{array}$ \\
\hline $\begin{array}{l}\text { Инновационный } \\
\text { кластер }\end{array}$ & $\begin{array}{l}\text { «Целостная система новых технологий и продуктов, между } \\
\text { которыми имеется взаимосвязь, и которые можно рассматри- } \\
\text { вать в качестве сосредоточенных на определенном временном } \\
\text { отрезке и в конкретном экономико-организационном про- } \\
\text { странстве» [17] }\end{array}$ & $\begin{array}{l}\text { Глубокий А., Акулич } \\
\text { М. }\end{array}$ \\
\hline \multicolumn{3}{|c|}{ Инновационный медицинский кластер } \\
\hline $\begin{array}{l}\text { Научно- } \\
\text { образовательный } \\
\text { инновационный } \\
\text { медицинский кла- } \\
\text { стер }\end{array}$ & $\begin{array}{l}\text { «Территориальное или профильное функциональное объедине- } \\
\text { ние организаций, осуществляющих образовательную деятель- } \\
\text { ность и (или) научную (научно-исследовательскую) деятель- } \\
\text { ность, подведомственных Министерству здравоохранения } \\
\text { Российской Федерации, создаваемое в целях взаимодействия } \\
\text { между участниками кластера для решения стратегических } \\
\text { задач в сфере охраны здоровья граждан» [5]. }\end{array}$ & $\begin{array}{l}\text { Приказ } \\
\text { Минздрава России } \\
\text { от «Об организации } \\
\text { работы по форми- } \\
\text { рованию научно- } \\
\text { образовательных } \\
\text { медицинских класте- } \\
\text { ров» }\end{array}$ \\
\hline $\begin{array}{l}\text { Инновационный } \\
\text { медицинский кла- } \\
\text { стер }\end{array}$ & $\begin{array}{l}\text { «Комплексная структура, объединенная одним технологи- } \\
\text { ческим процессом, конечным продуктом которого является } \\
\text { медицинская инновация, созданная усилиями всех участников } \\
\text { процесса, включающего представителей науки, практического } \\
\text { здравоохранения, органов власти, медицинского образования } \\
\text { и медицинского бизнеса» [10] }\end{array}$ & $\begin{array}{l}\text { Андреева И.Л., Абра- } \\
\text { мова И. Ю. }\end{array}$ \\
\hline
\end{tabular}


Определений «медицинский кластер» и близкие к нему не так много, значительно больше определений инновационного кластера, нами были рассмотрены некоторые из них.

Авторами было принято решение не ограничивать исследование только медицинскими кластерами, т.к. дальнейший анализ кластеров медицинского профиля в РФ показал ошибочность таких ограничений, особенно в рамках развития междисциплинарного подхода к формированию и развитию кластеров.

Различные авторы выделяют большое количество характеристик, присущих кластерам в медицине как экономическим структурам:

- взаимосвязанность;

- географическая концентрация;

- разнопрофильность;

- взаимодополняемость и взаимодействие;

- инновационность;

- сотрудничество и конкуренция.

Спецификой медицинских кластеров является:

- оказание высокотехнологичной медицинской помощи;

- обеспечение диагностики, лечения, профилактики, реабилитации;

- продвижение медицинских инноваций;

- реализация технологических цепочек для восстановления здоровья;

- ориентация на развитие биомедицинской и фармацевтической промышленности;

- ориентация на медицинский туризм.

Данные особенности были учтены в формулировке определения.

Итоговое определение с учетом всех выделенных особенностей инновационных медицинских кластеров, получилось следующим:

Инновационный медицинский кластер объединение организаций различных форм соб- ственности, инфраструктурных объектов и органов власти, осуществляющих деятельность по оказанию медицинской помощи, научноисследовательскую, образовательную, производственную, инвестиционную, инновационную, сбытовую, регулирующую и другие виды деятельности, направленные на создание и практическое использование инноваций в сфере здравоохранения.

\section{Заключение}

Авторы намеренно отказались от использования территориального или отраслевого объединения, т.к. считают, что для разработки и внедрения инноваций в медицине необходимость в этом отпадает. Кроме того, все большее число инновационных медицинских разработок формируется в сфере робототехники, нанотехнологий, биохимических исследований, создания новых материалов и других отраслях, относящихся скорее к техническим отраслям.

Опыт создания национальных медицинских исследовательских центров показал, что ядром разработки инноваций могут быть как научноисследовательские, так и медицинские и образовательные организации, хотя в независимости от первоначального профиля деятельности такой организации, в составе НМИЦ появляются образовательные, производственные, внедренческие, фармацевтические и другие отделы, направленные на комплексное изучение определенной сферы медицины.

По итогу анализа существующего опыта, стало очевидно, что необходимо совершенствовать кластерный подход для развития рынка медтехники и масштабировать его, так как отдельные позитивные примеры применения кластерного подхода в производстве медицинской техники не получили в настоящее время распространения.

\section{Библиографический список}

1. Федеральный закон от 29.06.2015 № 160-ФЗ (ред. от 26.07.2019) «О международном медицинском кластере и внесении изменений в отдельные законодательные акты Российской Федерации».

2. Федеральный закон от 22.07.2005 № 116-ФЗ (ред. от 18.07.2017) «Об особых экономических зонах в Российской Федерации».

3. Распоряжение Правительства РФ от 17.11.2008 № 1662-р (ред. от 28.09.2018) «О Концепции долгосрочного социально-экономического развития Российской Федерации на период до 2020 года» (вместе с «Концепцией долгосрочного социально-экономического развития Ро.

4. Постановление Правительства Российской Федерации от 23.04.2010 № 282 (ред. от 28.09.2018) «О национальной нанотехнологической сети» (вместе с «Положением о национальной нанотехнологической сети»).

5. Приказ Минздрава России от 26.11.2015 г. № 844 «Об организации работы по формированию научнообразовательных медицинских кластеров». 
6. Прогноз Прогноз социально-экономического развития Российской Федерации на 2018 год и на плановый период 2019 и 2020 годов.

7. Проект Постановления Правительства Российской Федерации «О внесении изменений в государственную программу Российской Федерации «Экономическое развитие и инновационная экономика» (подготовлен Минэкономразвития России 29.12.2016) [Электронный ресурс]. URL: http://www.garant.ru/products/ipo/ prime/doc/56598089/.

8. Закон Алтайского края от 03.10.2008 № 87-3С (ред. от 06.04.2009) «О внесении изменений в закон Алтайского края „Об оказании медицинской помощи на территории Алтайского края“».

9. Азимут научных исследований. Сборник статей. 2017 Tом 6 № 4(21). [Электронный pecypc]. URL: http:// napravo.ru/wp-content/plugins/download-attachments/includes/download.php?id=2331\#3.

10. Андреева И.Л., АбрамоваИ.Ю. К вопросу организации центров современных медицинских технологий в субъектах Федерации // Вестник новых медицинских технологий. 2008. № 4. С. 217-219.

11. Артамонова Г. В., Данильченко Я.В., Костомарова Т.С., ЧеркассН.В., Барбараш Л. С. Кластерный принцип повышения результативности научно-образовательной и медицинской деятельности // Менеджер здравоохранения. 2015. № 3. URL: https://cyberleninka.ru/a.

12. Беляков В.К., Пивень Д. В., Антонов Д. П. О проблемах инновационной политики в отечественном здравоохранении и необходимости создания кластеров медицинских инноваций. //Менеджер здравоохранения.2008. - № 1.- С. 4-11.

13. Биомедицинские кластеры в мире: факторы успеха и истории лучших / Е.А.Исланкина, Е.С.Куценко, Ф.Н. Филина, В.И. Панкевич и др.; Фонд Международного медицинского кластера; Нац. исслед. ун-т «Высшая школа экономики».- М.: НИУ ВШЭ, 2019.- 160 с. -15.

14. Биотехнологический инновационный территориальный кластер Пущино [Электронный ресурс] // Портал Инновации в России: сайт.-URL: http://www.innovation.gov.ru/node/3567 (дата обращения 17.03.2020).

15. Бирюков А.В. Преимущества современных инновационных кластеров // ТДР. 2009. № 1.- [Электронный ресурс] - Режим доступа: URL: http://cyberleninka.ru/article/n/preimuschestva-sovremennyh-innovatsionnyhklasterov (дата обращения 04.05.2020).

16. Бирюков А.В. Формирование инновационных кластеров в высокотехнологичных отраслях промышленности: на примере ОПК России. Диссертация на соискание степени д.э.н., М., 2009.

17. Глубокий А., Акулич М. Инновации и инновационные кластеры: что раньше - «курица» или «яйцо»? // Маркетинг: идеи и технологии, сентябрь, 2015 С. 12-18.

18. Губин А.В., Овчинников Е.Н., Стогов М. В., Городнова Н. В. Региональный медицинский кластер: организация и перспективы развития // Пространственная экономика. 2017. № 3. URL: https://cyberleninka.ru/article/n/ regionalnyy-meditsinskiy-klaster-organizatsi.

19. Жаворонков Е. П. Кластерная стратегия в развитии медицинских организаций // Медицина и образование в Сибири. 2013. № 1. С. 58-65.

20. Захарова Е.Н., Ковалева И.П. Формирование медицинского кластера как направление интеграционного взаимодействия субъектов региональной медицинской сферы // Вестник Адыгейского государственного университета. 2013. № 4 (131). С. 21-27.

21. Инновационный кластер информационных и биофармацевтических технологий Новосибирской области [Электронный ресурс] // Портал Инновации в России: сайт.— URL: http://innovation.gov.ru/node/3563 (дата обращения 11.05.2020).

22. Инновационный территориальный кластер «Фармацевтика, медицинская техника и информационные технологии» [Электронный ресурс] // Центр кластерного развития Томской области: сайт.- URL: http:// www.fmt.innoclusters.ru/ru/cjeli_i_zadachi (дата обращения 11.

23. Инновационный кластер Ульяновской области [Электронный ресурс] // Агентство технологического развития: сайт.-URL: http://atr73.ru/innovacyonnyi_cluster/ (дата обращения 11.05.2020).

24. Казанцев А. К. Инновационные кластеры в региональных стратегиях / А. К. Казанцев, И. А. Никитина // Вестник СПбГУ.- 2011.

25. Кластер «Фармацевтика, биотехнологии и биомедицина» [Электронный ресурс] // Калужский фармацевтический кластер: сайт._ URL: http://www.pharmclusterkaluga.ru/about-cluster/ (дата обращения 11.05.2020).

26. Кластер «ФИЗТЕХ XXI» [Электронный ресурс] // Портал Инновации в России: сайт.- URL: http://www. innovation.gov.ru/node/3562 (дата обращения 11.05.2020).

27. Кластер медицинской и фармацевтической промышленности [Электронный ресурс] // Центр кластерного развития Санкт-Петербурга: сайт.- URL: https://spbcluster.ru/klaster-meditsinskoj-i-farmatsevticheskojpromyshlennosti/ (дата обращения 11.05.2020). 
28. Кластер «SMART TechnologiesTomsk» [Электронный ресурс] // Инновационный портал Томской области: сайт._URL: http://inotomsk.ru/innoclusters/smart-technologies-tomsk/ (дата обращения 11.05.2020).

29. Ковалюнас Н. В. Медицинский кластер как универсальная модель регионального развития // Науки о жизни. Наука региональная и глобальная. Самара: Медиа-книга, 2015. С. 50-53.

30. Консорциум инновационных кластеров [Электронный ресурс] // ОЭЗ «Дубна»: сайт. - URL: http://dubna-oez. ru/innovations/clusters/consortium/ (дата обращения 11.05.2020).

31. Кумакова С. В. Инновационные кластеры как механизм проектной реализации стратегии развития региона в рамках «умной специализации» //Россия: тенденции и перспективы развития. - 2019. - № . 14-1.

32. Лазуткин М. Н. Российская кластерная обсерватория. [Электронный ресурс] // Российская кластерная обсерватория: сайт. - URL: http:// cluster.hse.ru/news/1545/ (дата обращения 16.01.2020).

33. Лебединская Ю.С., Яковец О.Н. Медицинский кластер: понятие и специфические черты // АНИ: экономика и управление. 2016. № 2 (15). URL: https://cyberleninka.ru/article/n/meditsinskiy-klaster-ponyatie-ispetsificheskie-cherty (дата обращения: 29.04.2020).

34. Лебединская Ю. С., Яковец О. Н. Медицинский кластер: понятие и специфические черты //Азимут научных исследований: экономика и управление.- 2016.- Т. 5.- № . 2 (15). [Электронный ресурc]. URL: https:// elibrary.ru/item.asp?id=26382802.

35. Любимов А.П.Перспективы создания российских инновационных кластеров //Представительная властьXXI век: законодательство, комментарии, проблемы.- 2013.- № . 5-6.- С. 14-19. [Электронный ресурс]. URL: https://elibrary.ru/item.asp?id=20869011.

36. Методические рекомендации по реализации кластерной политики в субъектах Российской Федерации (утв. Минэкономразвития РФ 26.12.2008 № 20615-ак/д19).

37. Мещерякова Ж. В. Медицинский кластер в системе здравоохранения региона как инновационная модель интеграции субъектов государственно-частного партнерства // Экономика и бизнес: теория и практика.2017. - № 3. - С. 43-45.

38. Министр Вероника Скворцова приняла участие в заседании Совета по развитию социальных инноваций субъектов Российской Федерации при Совете Федерации [Электронный ресурс] // Министерство здравоохранения Российской Федерации: сайт.- URL: https://www.ros.

39. Монастырный Евгений Александрович Инновационный кластер // Инновации. 2006. № 2. URL: https:// cyberleninka.ru/article/n/innovatsionnyy-klaster (дата обращения: 04.05.2020).

40. Направления деятельности [Электронный ресурс] // Кластер ядерно-физических и нанотехнологий: сайт.URL: http://dubna-cluster.ru/cluster/about (дата обращения 11.05.2020).

41. Научно-производственный кластер «Сибирский наукополис» [Электронный ресурс] // Научнопроизводственный кластер «Сибирский наукополис»: сайт.- URL: http://icnso.ru/about.html (дата обращения 11.05.2020).

42. О государственной поддержке развития инновационных территориальных кластеров [Электронный ресурс] // Минпромторг России: сайт._ URL: http://minpromtorg.gov.ru/common/upload/files/docs/O_ gosudarstvennoy_podderzhke_razvitiya_innovatsionnykh_territoria.

43. Отобраны участники приоритетного проекта Минэкономразвития по развитию инновационных кластеров [Электронный ресурс] // Министерство экономического развития Российской Федерации: сайт. - URL: http://old.economy.gov.ru/minec/about/structure/depIno/2016.

44. Родионов Д. Г., Афанасов А. Ю., Горовой А.А. Зарубежный опыт формирования и реализации региональной кластерной политики //Мир экономики и права. - 2014. - № . 6. - С. 4-16..

45. Родионов Д.Г., Кичигин О.Э., Селентьева Т.Н. Особенности оценки конкурентоспособности инновационного регионального кластера: институциональный подход // Научно-технические ведомости СанктПетербургского государственного политехнического университета. Экономические науки. 2019. № 1 (12).

46. Родионов Д.Г., Кудрявщева Т. Ю. Механизм и принципы формирования кластерной промышленной политики // Инновации. 2018. № 10. С. 81-87.

47. Смирнов, Иван Владимирович. Механизм развития интеграционных процессов в инновационной среде кластера: диссертация ... к.э.н.: 08.00.05 ФГБОУ ВО «Башкирский государственный университет». 2020.

48. Сосновский А.А. Основные признаки управляемости медицинского кластера в рамках единого информационного пространства // Современная наука. 2010. № 2. URL: https://cyberleninka.ru/article/n/osnovnyepriznaki-upravlyaemosti-meditsinskogo-klastera-v-ramka.

49. Сунгатов Р.Ш., Киселев С.В., Сосновский А.А. Специфика управления потоками информационных услуг в рамках медицинского кластера // Вестник казанского технологического университета. 2010. № 7. С. 30-36. 
50. Титова Н. Ю., Титова Ю. В. Медицинский кластер: понятие и особенности // АНИ: экономика и управление. 2017. № 4 (21). URL: https://cyberleninka.ru/article/n/meditsinskiy-klaster-ponyatie-i-osobennosti (дата обращения: 29.04.2020).

51. Толстопятенко М.А., Зиньковская Н.В. Фармамедицинский кластер: модель и проблемы формирования // Проблемы экономики, финансов и управления производством. 2013. № 33. С. 94-102.

52. Чернова Жанна Борисовна. Формирование и модернизация региональных экономических кластеров на основе государственной поддержки: диссертация ... кандидата экономических наук: 08.00.05. Рос. эконом. ун-т им. Г. В.Плеханова. 2017. [Электронный ресурс]. URL: http://dlib.rsl.ru/rs101009000000/rs101009680000/ rs101009680557/rs101009680557.pdf.

53. Ядерно-инновационный кластер г. Димитровграда [Электронный ресурс] // Ядерно-инновационный кластер г. Димитровграда: сайт. - URL: https://cluster-dgrad.ru/rus/o-klastere (дата обращения: 11.01.2020).

54. Community Framework for State Aid for Research and Development and Innovation [Электронный ресурс] // Cluster Navigators: сайт. - URL: clusternavigators.com/content/view/28/75/ (дата обращения: 12.02.2020). 